\title{
Japanese Crimes in Nanjing, 1937-38 : A Reappraisal
}

\author{
Jean-Louis Margolin
}

\section{(2) OpenEdition}

Journals

Édition électronique

URL : http://journals.openedition.org/chinaperspectives/571

DOI : 10.4000/chinaperspectives.571

ISSN : 1996-4617

\section{Éditeur}

Centre d'étude français sur la Chine contemporaine

\section{Édition imprimée}

Date de publication : 1 février 2006

ISSN : 2070-3449

\section{Référence électronique}

Jean-Louis Margolin, « Japanese Crimes in Nanjing, 1937-38: A Reappraisal », China Perspectives [En ligne], 63 I january - february 2006, mis en ligne le 20 décembre 2006, consulté le 14 novembre 2019 URL : http://journals.openedition.org/chinaperspectives/571; DOI : 10.4000/chinaperspectives.571

Ce document a été généré automatiquement le 14 novembre 2019.

(c) All rights reserved 


\title{
Japanese Crimes in Nanjing, 1937-38 : A Reappraisal
}

\author{
Jean-Louis Margolin
}

Less politics, more history, please !
"Robespierristes, anti-robespierristes, nous vous crions grâce : par pitié, dites-nous, simplement, quel fut Robespierre"

For many Chinese worldwide, Nanjing is considered a tragedy of proportions equal only to Hiroshima and Auschwitz ${ }^{2}$. Many Japanese still try hard, if not to completely deny their army's crimes, at least to minimise them and to find excuses for them. Yet, and with a reasonable degree of precision, the evidence, the process, the responsibilities and the dimensions (including the fiercely argued about number of victims) of those events are not too difficult to outline. No other single massacre in Asian history, and few during World War II, including in Europe, have had so many testifying witnesses ! Foreign academics (including professors of sociology and history), reporters, missionaries, diplomats and businessmen, all familiar with writing and with China, often fluent in Chinese, have provided us with a profusion of narratives, all the more reliable as those writings came with or followed very closely the events.

But the very centrality of Nanjing in the assessment of the whole 1937-45 war between Japan and China has unfortunately led to much ideologically motivated obscuring, on both sides. Strangely, with the passing of time, the range between the diverse evaluations of victims has not narrowed, but widened (at the last count, between 50 and $430000 . .{ }^{3}$ ), some Japanese veterans, politicians and historians (but definitely not the majority) still consider it a matter of honour and respect for their fallen soldiers to deny either the facts, or the figures, or both ; and many Chinese (in China, and maybe even more in the United States) consider it a matter of national pride to add new layers to the amount of victims. Any attempt to discuss, not only the facts, but even the official 300,000 figure (posted in bold on the wall of the Nanjing Massacre Memorial) may trigger a diplomatic row. Historical research has been the loser : there has been no 
serious attempt to clarify other wartime massacres in China, such as in Wuhan in 1938, or Changsha in 1944, and even less to make a comprehensive assessment of Japanese crimes in China, outside the doubtful present official figure of 35 million violent deaths. Comparing Nanjing with Singapore in 1942 (the infamous Sook Ching operation) ${ }^{4}$, or Manila in 1945, could prove very rewarding, but historicising an issue also means to run the risk of trivialising it, and turns against both heroisation and damnation. Nanjing could even be proved not to be the biggest Japanese massacre in China (for all of Asia, Manila-itself very little studied-probably comes first). Therefore, we don't even know in what measure Nanjing has been the exception or the rule in the behaviour of Japanese troops in China.

3 A similar magnifying effect could be pointed to in the case of Auschwitz. It is still considered as the emblematic crime scene of the Jewish genocide, even as we now know that the number of victims (probably around 900,000) represents only one-sixth of Jewish deaths, and is only slightly higher than the figure for Treblinka (around $800,000)$. That can be explained by the survival, despite terrible ordeals, of a number of witnesses at Auschwitz, although almost every Jew was killed on arrival in Treblinka. We should at least consider the possibility of a similar effect for Nanjing.

There is a great difference, however, at least, at present. The number of Auschwitz deaths has been reassessed many times (and is still not finalised), from an initial figure of four million (the official figure in communist Poland) to less than a million. But these reassessments have largely been made by Jewish historians, without major controversies, without accusations of revisionism, and without political implication. Outside a vocal but quite insignificant fringe of deniers, totally discredited (except maybe in a few East European countries) academically and politically, consensus exists regarding the essential features and dimensions of Nazi crimes. German historians themselves play an essential-and now uncontroversial-role in the advancement of our knowledge on the Shoah. There are still grey areas and areas of controversy, occasionally bitter, but they concern essentially details (chronology, personalities, organisations, local history...) and interpretations ${ }^{5}$. The situation is very different in Asia.

5 This paper will present a reassessment of the tragic first weeks that followed the Japanese occupation of the then Chinese capital, on December 13th $1937^{6}$. It will concentrate on the points of greatest contention, and use mostly data from Western and Japanese ${ }^{8}$ witnesses or perpetrators. Reliable Chinese sources are less obvious, but official wartime publications ${ }^{9}$ and the collection of testimonies painstakingly gathered since the 1970 s by Honda Katsuichi ${ }^{10}$ are of some help.

How?

6 Chinese people living in Nanjing between December 1937 and February 1938 (when a degree of normalcy started to be restored) could rightly have had the feeling of living in a pandemonium of violence and cruelty in which an army of monsters did all they could to make their existence as miserable as possible-when they did not kill them outright.

The violence of war

7 Nevertheless, what happened was not indiscriminate or senseless violence. It is essential that we differentiate here between three different types of mass violence, as 
the circumstances and consequences differed widely. The first could be called a "war massacre". For the Japanese troops who had suffered huge losses in the battle for Shanghai (August-November), taking over Nanjing proved easy, and their losses were small (around 1,000 deaths). Things were completely different for the Chinese. Chiang Kai-shek, as late as December 11th, had ordered a defensive position to be taken behind Nanjing's thick walls, the gates of which had almost all been blocked. But on December 12th, he ordered an immediate retreat, before any significant Japanese attack. An awful panic followed, as many officers left their men behind while they themselves fled the fighting, and as uninformed units started shooting at the "deserters". The city had been almost completely encircled by the Japanese, and the only obvious way out was towards the Yangzijiang that had then to be crossed. Thousands died : crushed to death trying to cross the only narrow gate, falling from the city walls, drowning in the icy water when their overcharged embarkations capsized or when they attempted to swim across, or killed by their own troops.

Many more, probably, were killed by fire from the Japanese flotilla, already positioned on the river. The fighting was then completely one-sided, as the Chinese had almost no means and even less will to counterattack. Nevertheless, as the Nanjing garrison had refused to surrender on December 10th, to the duly transmitted ultimatum of the Japanese army, the massacre contradicted not at all the accepted laws of war. What army ever failed to take full advantage of a similar disequilibrium, the last case to date being probably the destruction by the US Air Force of the Iraqi army retreating from Kuwait in 1991 ?

The extermination of Chinese soldiers

9 But what happened next was totally contrary to the age-old and universally accepted laws and customs of war, and, particularly, to the 1929 Geneva Convention on Prisoners of War, signed but not ratified by Japan ${ }^{11}$. Seen by Japanese Headquarters, it was probably a follow-up of a battle that should have led to the total crushing of Chiang's forces. But the most extensive crime (by universal morality, by international law) that took place in (or, more precisely, around) Nanjing was the systematic massacre of unarmed Chinese soldiers. Most had surrendered, frequently in whole units, quite confidently: some of their Japanese guards remarked that they would have been crushed in no time if those masses of prisoners, sometimes not fully disarmed, had turned unruly. Some Japanese, afterwards, talked about the numerous plainclothes soldiers they also arrested as if discarding their uniform had been sufficient reason to kill them. In any case the argument is very poor: the uniformed soldiers who surrendered, were treated as badly as those in plain clothes, who had tried to blend into the civilian population. It could even be argued that, if they had not been given good reason to fear for their lives, most would not had tried to hide.

The massacre was cold-blooded and deliberate. It lasted several weeks, even if most were killed in the first few days : as late as January, several thousand "plainclothes soldiers" were still arrested to be executed. Few of the trapped soldiers had a chance to escape death. Even inside the Safety Zone, refugee camps were combed again and again, and all Chinese had to register from December 26th: according to Rabe, that led to some 20,000 arrests $^{12}$. All men of fighting age were closely scrutinised. A military-style haircut, a paler forehead (soldiers wear headgear), a red mark on the rifle-bearing shoulder meant sure death. Thousands of male civilians in the 15 to 45 age group (not very numerous, many had left the town without their families) were taken, as it 
appeared to many officers in charge so much easier to arrest everybody that could have been a soldier, according to the principle: "better ten innocents dead than an exsoldier free". Significantly, on the evening of December 13th, the 6th Brigade of the 9th Division issued the directive : "Since the defeated enemy soldiers are believed to be in plainclothes, you must arrest any person who is suspected of being so and detain him at an appropriate location (...) You should regard every adult man up to middle age as a straggling or plainclothes soldier, and arrest and detain him" ${ }^{13}$. Regarding the execution orders, most were probably transmitted orally, or written in the ambiguous way common to all planners of "final solutions". But a few very explicit directives have emerged, such as the regimental order received on December 13th by the 1st Battalion of the 66th Infantry Regiment, 114th Division : "Execute all the prisoners in accordance with the brigade's order. Regarding the method for execution, what about making groups of dozens each, tying them up, and shooting them one by one ?"

11 Such a modus operandi appears quite typical. What mattered was speed and efficiency. The surprise factor was essential. A number of prisoners of war (POWs) were bayoneted or decapitated with swords-that was great fun for several soldiers, and good training according to their officers-, but it was much faster and more practical, considering the immensity of the task, to mow down big groups with the concentrated fire of several machine guns, then to burn the bodies using gasoline. Several Chinese soldiers went through the ordeal, without being killed, hence our abundant knowledge on that point. Everywhere the targets, the processing and the results were more or less the same, whatever the Japanese army unit, the date, or the previous behaviour of the POWs. No significant numbers ever escaped death to be sent to a prisoner camp or to be released. The luckiest could be selected as coolies by a Japanese army chronically deficient in logistics. Yet even those men frequently ended by being murdered, being no longer needed. General Staff officer Sakakibara confided his disappointment: "I planned to use the interned prisoners as labour in Shanghai, but they were killed while I was away on an official trip" ${ }^{15}$. To the best of our knowledge, no Japanese soldier was punished, at least during that period, for such misdeeds.

The goal was to win the war, but also to destroy the basis of the Guomindang government. Thus every government employee was considered as an enemy. More than fifty of the 400 policemen "given" by the former municipality to the International Committee (IC) were arrested and murdered, as well as a handful of street sweepers, and 43 of the 54 employees who had remained at their post in the electric plant, actually belonging to the private sector, had been mistakenly treated as government employees.

The multiple violence against civilians

13 The third and last category of violence struck people as civilians, and not (as for the young men) as would-be soldiers. This was more pervasive and lasted longer, but was less systematic and less deadly. It is divided into three sub-categories. The countless rapes ( 8,000 to 20,000 , according to Western witnesses) were the main cause of the terror in which refugees passed those months. Taking women within the main target age range (say, between 15 and 40) and numbering to a maximum of 50,000 (see second part for the population figures), and also taking into account the frequent multiple rapes that many of them suffered, it can safely be deduced that, in the space of about two months, a huge portion of that age group (most probably between $10 \%$ and $30 \%$ ) were victims of sex crimes. Some days (or more precisely nights) of December, 
according to IC members, upwards of 1,000 women were raped. Few women could feel safe : on the university campus alone, the youngest victim was nine years old, the oldest seventy-six.

Several circumstantial factors worsened the ordeal : soldiers generally acted in small groups, and thus most rapes seem to have been collective ; they often took place in full view of other women refugees, less often in front of the terrified families; women were frequently kidnapped, to places where the soldiers were housed, and released only the next morning, or sometimes after a few days or weeks-in such cases they could be used as servants during the day, as sex slaves at night; violence (often using the ubiquitous bayonet) was the rule when the victim or her relatives resisted, and murder was not the exception, even if it remained infrequent ${ }^{16}$. In a number of cases, women were incited or forced into prostitution : the "Comfort Women" system, so extensive later on, seem to have had its origin in Nanjing.

We have just mentioned the murder of family members (or friends or neighbours) during rapes. More generally, the slightest unwillingness to let Japanese soldiers go their way, the slightest reluctance to follow their orders (generally given in Japanese, sometimes in broken Chinese...) and any attempt to hide or flee could lead easily to death : according to Reverend John Magee, of the IC, Japanese soldiers "not only killed every prisoner they could find but also a vast number of ordinary citizens of all age. Many of them were shot down like the hunting of rabbits in the streets. There are dead bodies all over the $\operatorname{city}^{17}($...). So many of the Chinese are timid and when challenged foolishly start to run. This is what happened to that man (...) These two Jap. soldiers were no more concerned than if they had been killing a rat and never stopped smoking their cigarettes and talking and laughing" ${ }^{18}$. These almost random murders form the second sub-group of violence against civilians. The most thorough investigation into these was made after March 1938 by a sociologist of Nanjing University and IC member, Lewis S.C. Smythe, assisted by some twenty students. The data for the villages of Jiangning xian, close to Nanjing, are very revealing. Among the 9,160 recorded murders, males represent more than three-quarters. 59\% of them belong to the $15-44$ age group, targeted as possible soldiers, but only $11 \%$ of female deaths belong to the same group-the one most targeted for rapes-, 83\% being 45 or above (and 39\% over $60)$. That seems to confirm what many individual cases show: older people, and especially older women, whose families thought that they had a better chance of being respected by the Japanese, remained in the house or the shop to try and preserve it, when the rest of the family went into hiding, or into the refugee camps of the Safety Zone. Yet the soldiers seldom spared them during their looting and arson expeditions, many being burned alive in their own houses. Numerous mothers and grandmothers perished trying to stop their daughters'/granddaughters' rape. Many individual stories seem to indicate that, during the rapes, family members were more often killed than the raped girl. The last important information in Smythe's data concerns children : the age group 5-14 years represents $8 \%$ of the deaths (slightly more for boys than for girls), and the $0-4$ years about $2 \%$. The Japanese were not compulsive baby-killers ${ }^{19}$.

The third and last sub-group of anti-civilian violence is made up of the extensive looting, arson and destruction by fire that made life almost impossible in the parts of town not included in the Safety Zone. In a city that had been little damaged by the effects of war itself, about one third of the buildings were partly or completely 
destroyed, over several weeks, and in a very systematic way. People were robbedincluding of the few things and the little food they had taken with them to the refugee camps-, but the worst was the thorough plundering of the shops, row after row, and the subsequent fires. They could not be protected by the IC, as the Zone mostly included administrative, educational and medical buildings. It was well organised: officers were leading their men in those inglorious expeditions; whole convoys of trucks then removed the looted items. The highest ranking officers felt no shame in grabbing their (choice) share of the plunder: Lieutenant General Nakajima Kesagoformer head of the Military Police, the dreaded Kempeitai-replied to his commanderin-chief, General Matsui Iwane, who was blaming his greed : "Why does the stealing of art pieces matter so much when we are stealing a country and human lives? Who would benefit from these items even if we left them behind ?"20 . Outside its cynicism, that answer says something about the true intentions of the Japanese (or maybe only of some Japanese?): certainly not a genocide of the Chinese population, but its impoverishment, the disintegration of the society, the destruction of political structures, the deterioration of culture ${ }^{21}$. All that goes well with the initial Japanese attempt to divide China into as many fragments as possible (that policy was reversed in 1939-1940, due to the unexpected persistence of Chinese resistance), and with the frightening development of drug pushing and consumption, that so alarmed the IC members as early as the spring of 1938 .

How many?

The body count should have remained a secondary issue: the evidence is overwhelming, and scientifically undeniable, of large-scale massacres in Nanjing. And there is also sufficient evidence to show that the killing of the POWs was systematic as well as organised according to military hierarchy, sufficient evidence too of the general acceptance (if not participation) of the army leaders regarding the violence against civilians. That knowledge is not recent: it provided the basis of the verdict of death returned against General Matsui, in 1948.

But so much smoke has blurred the legitimate scientific debate on the number of victims that a reappraisal of that question is unavoidable. The issue is not an easy one, as the "bottom line" is the aggregate of several mass murders among different target groups : the POWs, the civilians arrested as plainclothes soldiers, the raped women and their families or friends, not to forget the "random" or "accidental" killings, often connected to looting and arson. The difficulty is such that a number of authors, following the questionable methods used during the Tokyo Trial, have tried to find "shortcuts" towards the truth. But, in our opinion, these shortcuts lead nowhere.

Two wrong ways towards the truth

The seemingly easiest way could be the inventory and detailed evaluation of all largescale killing: no-one contests that most deaths took place during mass murders, in Nanjing or, more frequently, in its vicinity. A number of documents (records of Japanese army units, Japanese soldiers' diaries, oral testimonies or affidavits by Chinese survivors or witnesses, diaries and letters of Westerners from Nanjing, etc) give fairly precise figures on probably all the mass executions. The troubles start with the enumeration of these events : they took place over a few days, in a reduced space, and consequently it is often almost impossible to decide if two different sources are describing two different massacres or one and the same, with a slightly different timetable and/or location. The problem is all the more serious when these two sources 
each talk of the killing of about 50,000 people... ${ }^{22}$. The troubles develop further with the assessment of each massacre. In face of a crowd, the spontaneous tendency always is to overestimate it (everyone should do the experience of counting it afterwards, at least once in one's life). Under the awful stress of a mass killing, one can guess that the overestimation must be even more pronounced. Quite obviously the escaped victims, lying until dark under piles of dead bodies, generally injured themselves, were in no position to provide an accurate or perhaps even reliable figure. The Japanese units were overwhelmed by the huge numbers of prisoners, and by the insistence of their hierarchy on disposing of them as soon as possible. At least for the biggest massacres (those over, say, 2,000 people), it is quite obvious that they did not count them seriously. Furthermore it should be remembered that they were not specialised units, such as the SS in the German army, and that mere opportunism led them to overestimate the number of victims. Consequently that method is unable to produce solid numbers. Furthermore the mistake is to tend to overestimates.

Another method, that could be more reliable-to which the Tokyo International Military Tribunal for the Far East (IMTFE) gave its seal of approval-, is based on burial data. Very detailed records have been kept, especially of the Chinese Red Swastika, which was working in close co-operation with the IC who provided part of the financing. That organisation gave a final resting place to 42,000 bodies between December 1937 and April 1938. That figure may be accepted, and it is quite certain that, in such a period, it corresponds to an overwhelming majority of violent deaths. But that does not mean in any way that the Japanese murdered something like 40,000 people. In fact, to that figure should be added the unknown but large number of bodies thrown into the wide Yangzijiang (most mass killings took place on its banks); and from it should be subtracted an equally unknown but large number of bodies of Chinese soldiers who actually died during the fighting (not necessarily killed by the Japanese, as explained previously), and who cannot be considered to have been murdered. The coup de grâce is given by the impossibility to know what percentage of the abandoned bodies the Red Swastika did bury. Families and neighbourhoods, for sure, did their part : their most active period, according to Red Swastika data, was in February, two months after the worst killings. The Japanese had given in December the awkward order to leave the bodies where they were, including in front of houses, even in the Safety Zone, and that order seems not to have been lifted before the end of January ${ }^{23}$. But, for obvious reasons, people must have tried to dispose of the decaying bodies as soon as possible. The problem is made even more complicated by the belated release (actually after war ended) of the burial statistics of another charitable society, the Buddhist Chunshantang. Never evoked by the IC members, it nevertheless claims to have buried 112,000 bodies. The figure appears utterly unreliable : it was only a small group (forty full-time workers), and would have buried almost 4400 bodies a day during the last three weeks of April ! Why would the Red Swastika have left its job so unfinished (its activity slackened after the first week of March)? How to explain that, after some normality returned from mid-February, both the Japanese garrison and the new municipal authorities could have borne leaving a mass of 100,000 bodies decaying for two more months, at the start of the warm season, just outside Nanjing? Consequently, we can safely dismiss Chunshantang statistics as fabricated, but that does not imply that they (or some other societies, or individuals) did absolutely nothing. The end result : the burial statistics are too unreliable to be the basis of an evaluation. 
The problem of the remaining civilian population had left weeks before the arrival of the Japanese. A lot of people had every incentive people remained behind. Many Chinese localities, big or small, had lost even more people in similar circumstances, so great was the (justified) fear inspired by the Japanese : thus the November 20th issue of the Asahi Shimbun spots only 500 residents remaining in the large city of Suzhou to "welcome" the Imperial Army ${ }^{26}$. In France, in May-June 1940, ten million people (one-quarter of the total population, much more in the northern areas) abandoned their homes, although the German army behaved then far better than the Japanese in China.

The problem of the remaining-and killed-Chinese soldiers

The second figure is more difficult to establish, but absolutely decisive : as we may assume that almost all Chinese soldiers arrested by the Japanese were executed, the number of soldiers remaining in Nanjing on the evening of December 13th is very close to the number of POW murders. Only a few hundred, or more probably a few thousand, were able to hide long enough to safely leave the city when it started to reopen in February. Five component numbers have to be assessed. The most important is probably the total strength of the Nanjing Chinese garrison. It included 13 divisions, plus some artillery and military police units. At full strength that would have meant about 180,000 soldiers. But many of these units had been severely depleted during the Shanghai battle, and desertions were rampant. Yamamoto, after very thorough discussion, proposes a range of 80,000 to 130,000 soldiers, just before the final battle for Nanjing $^{27}$. On that point, there is no disagreement with Iris Chang and the other authors.

25 The next figure is the number of combat losses (the "war massacre" already described). Several authors have estimated this at a minimum of 10,000 . The third is the end result of the mentioned panic: at the very least one thousand, more probably several thousand. The utter disorganisation during the last days was also cause for the 
abandoning of the sick and injured soldiers, without or almost without medical care, in the hospitals or at the railway station ${ }^{28}$. Some days in November, up to 1,700 arrived in Nanjing, and many died therefore before or just after the arrival of the Japanese, to an estimate of around $9,000^{29}$. Finally, those who could safely cross the river should be numbered-at least a few thousand, probably more (a number fled early on). numerous than the number of inhabitants on December 13th. But we have also seen that there has been no wholesale killing, no genocide. In the thousands pages of diaries, letters, reports, dispatches, articles, there is not the slightest hint of a systematic attempt to make the Nanjing population disappear. The only exception were the young males, often mixed with the soldiers, and treated like them. Not surprisingly, in the available data (especially Smythe's), they form a clear majority of civilian deaths, even as there were many more females than males among those remaining. There is detailed information on 6,600 violent deaths and abductions of males inside the city : 4,200 abductions and 1,100 killings were committed against the age group 15 to 44 . The women (all ages) killed numbered $650^{30}$. We have already looked at the data for the vicinity of Nanjing : they present similar trends, even if the proportions of females and, among the males, of the other age groups are significantly higher: these differences probably demonstrate that the IC was efficient at protecting the civilians, except those regarded as possible soldiers. So, of a total of almost 16,500 detailed murders, in and around the city, males aged 15-44 make up about 9,500 (or 57\%). All females make up about 2,500 , or $15 \%$.

These statistics are entirely compatible with the qualitative indications one draws from the available documents. They also fit well with the burial statistics : the Red Swastika buried 208 men, but only 75 women, and 20 children. The Chunshantang data, in whatever value we may give to them, include $97 \%$ male bodies ; $2 \%$ women's, and less than $1 \%$ children $^{31}$. Nothing surprising there, if we accept that the overwhelming majority of the victims were soldiers and, among the civilians, men, most of them selectively arrested as would-be soldiers. The extremely small proportion of women and children among the bodies is also logical, if we accept that women or children were almost always killed individually, sometimes in the streets, more often during rapes and lootings, generally in the presence of or not far away from their families, friends or neighbours: their bodies were usually buried by those people, and escaped the collected statistics. On the contrary, there is no trace in all these data (including, ironically, in the much contested Chunshantang's data) of any large-scale massacre of 
civilians, outside the young adult males. There is especially no evidence that women or children were killed in large numbers, as Chang and so many authors claim.

Miner Bates-the Nanjing University historian, and IC member-sums up Smythe's enquiries (having taken part in them): "Our final estimate of the number of civilians killed in Nanking was 12,000, nine-tenths apart from military operations, and including many women, children, and aged men. That figure is in the ratio of one to every four families then in the city" ${ }^{\prime 32}$. Eight years later, appearing as an accusation witness during the Tokyo trial, Bates saw no reason to change his mind: "Professor Smythe and I concluded, as a result of our investigations and observations and checking of burials, that twelve thousand civilians, men, women and children, were killed inside the walls within our own sure knowledge. There were many others killed within the city outside our knowledge whose numbers we have no way of checking, and also there were large numbers killed immediately outside the city, of civilians" ${ }^{33}$. That last statement implies that 12,000 should be regarded as a minimum more than as a "final estimate". Nevertheless, if Bates could have imagined a final figure very significantly higher than his original one, he would not have stuck to it, especially as he was in Tokyo on the prosecution side. We do not know any convincing new evidence that should lead to the dismissal of these very important initial investigations, made by a group of people academically trained, constantly present and in charge (management, feeding, medical care, and of course protection) of the Nanjing population. It seems unbelievable that a large-scale massacre among that population could have fully escaped every one of them : even the killing of soldiers (who were not under their responsibility) outside the city walls were by and large known to them, or through survivors reaching the Zone, or through the burial operations of the Red Swastika.

31 Thus one may conclude, with a reasonable degree of safety, that between 12,000 and, say, 20,000 civilians were murdered inside the walls of Nanjing. If the immediate vicinity is included, the number could jump to 30,000 , or a bit more. That means huge mass murder : $5 \%$ to $8 \%$ of the remaining population of the city proper $(1.2 \%$ to $2 \%$ if the pre-war population is considered), or one family in four, as an average, having lost one of its members ${ }^{34}$. As a comparison, the "Bloody Week" that ended the Paris Commune in 1871 killed less than $1 \%$ of the Parisians-and it is still remembered as a major tragedy in French history, and struck the world at that time. Among the capital cities of World War II, Nanjing could only be compared to Manila and Warsaw (plus Amsterdam, Budapest, Vilnius, Riga and Berlin if the local Jewish populations transported to the death camps are included) for the percentage of its citizens deliberately murdered. And if we add the massacre of civilians to the "holocaust" of the POWs, we reach the 50,000-90,000 range, about $95 \%$ of them men ${ }^{35}$.

Why $?^{36}$ Nor a mere breakdown of discipline, nor a genocidal policy

Two common-and opposite-interpretations should be rejected first. The first has already been addressed: a "breakdown of discipline", a more or less spontaneous rampage by Japanese soldiers gone half mad with suffering and privation, and eager to take revenge on the Chinese who had inflicted on them serious losses $(40,000$, including 9,000 killed in action) during the Shanghai battle. It is the preserve of Japanese revisionists $^{37}$, but it is also shared, in a lower key, by many authors. However, if things had been so, one can wonder why massacres such as Nanjing, or worse, did not happen even much more frequently in war history. Furthermore, such an interpretation 
contradicts the numerous evidences showing that the killing of the POWs had been centrally organised, that officers of all ranks, as well as political leaders in Tokyo, were perfectly and early informed of the atmosphere of terror developing in Nanjing, and that, until February, they had not given a dime about it. Field officers-not the last to take part to rapes and lootings-were extremely lenient with all kind of atrocities against civilians, even as the slightest lack of respect towards superiors or mistakes in training or in war were punished with extreme severity.

Completely to the contrary, many authors refuse to make the distinction between the behaviour towards the POWs and towards the civilians, and consider that the goal of the Japanese, from the General Staff all the way down to enlisted men, was to kill and to rape as many Chinese as possible, men, women and children. Even if the word is more often suggested than pronounced, we are clearly facing a genocidal policy, according to them-first and foremost Iris Chang. If we follow her, the whole civilian population would have been massacred, if the IC members had not been so brave. Brave they were, indeed, and they saved many Chinese from murder, and even more from rape. But, from their own sad admission, they were almost completely unable to do anything for the soldiers or the young males arrested, even in their presence, in their own refugee camps, and even as they knew that they were taken away to be killed. Conversely, they were allowed to take efficient counter-measures against rapes and random violence (such as regrouping in closed halls huge groups of women, the youngest and prettiest staying as far as possible from the gates); they were allocated a few consular guards by the Japanese embassy, who stopped some soldiers ; even alone, they were almost always able to chase away the marauding groups of soldiers (Rabe putting proudly under their nose his Nazi swastika armband...), and even, not infrequently, to stop rapes in the middle of the act. And, to their own surprise, in these feats, none were killed, or seriously injured. Therefore, we can be certain that, for the Chinese soldiers, there were execution orders, that a disciplined army such as the Japanese accomplishes inflexibly. However, for the civilians, we have individual, unorganised actions, fully tolerated by the military hierarchy, but in which the perpetrators acted alone, without any cover from their superiors. It is also quite obvious that the soldiers had been given very strict instructions never to attack, or even counter-attack the Westerners : being American or German, they belonged to countries most important for Japan's external relations. Otherwise, how to explain such a difference of treatment between the easily brutalised or killed Chinese, and themselves ? Even drunk, even at the utmost of sexual excitation, no Japanese soldier ever forgot those instructions.

The three temporalities of Japanese violent behaviour

Back to square one, once again? Not completely : there are elements of pertinence in both rejected interpretations. For us, Japanese behaviour in Nanjing is tri-dimensional. Like Russian dolls, these three (temporal) dimensions are embedded one into the other. The shortest period has already been hinted at. Matsui, close to retirement (that was to be his last campaign), and not without bitter enemies at the Tokyo Headquarters as well as among his subordinates (Nakajima especially), wanted a short and decisive campaign that would terminate the war in a few months. He imposed on Tokyo a lightning offensive against the Chinese capital, defended by many of Chiang's best remaining troops. Contrary to expectations, there was to be no opportunity to kill them on the battlefield. As the Japanese had no logistics for POWs, the temptation was too great to solve the problem by finishing them off after the battle... A secondary 
advantage could be to trigger that way, through terror, mass desertions in what was left of the Chinese army. And, on that issue, Matsui was sure to receive Nakajima's full support. For the atrocities against civilians, the explanation is different. The Japanese were also operating according to highly deficient logistics, and had exacted much from their soldiers. The officers found expedient to present to their men the juicy carrot of food and women aplenty-the most praiseworthy units being granted the privilege of entering cities first. They already had the experience of living in the country, and their crossing of the $270 \mathrm{~km}$ between Shanghai and Nanjing was a succession of killing, rape and looting. Hence the criminal laxity observed in the capital. There too, there was a secondary advantage : terrorising the population of a symbolic city could show other Chinese their place and end their "arrogance", so often damned by Japanese propaganda. Similarly in Russia in 1941, the Germans felt confident in a rapid and decisive victory, and it was then that their violence had been at its worst, especially against Soviet POWs. Contrary to popular wisdom, supremely confident people can behave much worse than desperate ones.

That brings us to our second dimension, the medium period. It is difficult-and somewhat vain-to decide if Japan has been "fascist" or not. But everybody should agree that, in the late 1930s, the country was drifting fast towards the model presented by Italy and Germany, and that totalitarian, militarist, ultra-nationalist tendencies were strengthening by the day. We know that totalitarian regimes have a specific conception of war (parallel to their conception of politics). The victory should be absolute, the opponent country disappearing completely, or being transformed into a kind of colony. Obviously, that kind of fighting to the death tends to lead to an orgy of violence. And even (as in Italy or Japan) where racism was not central in state ideology, the radicality and bitterness of enmity necessarily gave birth to a "secondary racism", used as self-justification for the worst atrocities. That could explain why Japan, during World War II, behaved so much worse than during its previous armed conflicts (even if the tendency to treat Westerners better than Asians is an old one : during the Meiji period, Russians POWs were very correctly treated in 1905, but a cold-blooded massacre of Chinese had taken place when Port-Arthur was taken over, in November 1894).

The third dimension is the most long-term. Nanjing's massacres should be related to Japanese "war culture". That relatively new approach has been developed mostly by the American historian George L. Mosse ${ }^{38}$ and by a dynamic team of young French historians (Stéphane Audoin-Rouzeau, Annette Becker, etc.). Both have concentrated on World War I. The "war culture" approach draws heavily from sociology, ethnology and even archaeology. There is a degree of convergence with "history from below", mostly Anglo-Saxon. Emphasised are soldier's training, life, environment (including the "primary group" of army mates), fighting habits ; the ideological/political mobilisation of the civilians; the representations of friend and foe, of the nation, of the "glorious dead", etc. To our knowledge, little has been done in that field regarding the Japanese army $^{39}$. But it would prove fascinating. We already know that training and daily life in the barracks, even in peacetime, were awfully sordid and violent ("training by slapping"). Especially since the early 1930s, a mysticism of the "new samurai" had developed, with a fascination for the sword and the bayonet, and absolute contempt for surrender or "humanitarian" considerations. The group spirit, reinforced by the recruitment of units on a local basis, led to many feuds inside the army itself, but at war it may have given birth to the gangs of marauders that roamed Nanjing. 
Individually, the Japanese soldier seems to have been able to pass quite frequently from an extreme insensitivity to unexpected bouts of lachrymal sentimentality, for themselves but also, sometimes, for their enemies.

Finally, the study of the image of the enemy (sketched by John Dower for the Pacific $\left.W^{40}{ }^{40}\right)$ in the China War could be rewarding. According to their diaries and letters, the Japanese soldiers felt offended by the unexpectedly strong resistance of the Chinese : they should have behaved according to their image of weaklings, cowards, easy-to-beat soldiers (from the experience of the 1894-95 war). If they had not, it was not because their image was wrong; but was due to their hard-to-believe perfidy, to their maliciousness and their undeserved arrogance towards the Japanese. Private Ueba writes in his diary: "How can the Chinese keep fighting even with all that damage! I hate them" ${ }^{41}$. Stunningly, Omer Bartov describes exactly the same reaction among the German soldiers facing Russian resistance from 1941-and it led them to an upsurge of racial hatred and violence ${ }^{42}$. In both cases, a terrible revenge had to be taken. The enemy had forfeited every right by its lack of respect for the role that had been written for it ${ }^{43}$.

\section{NOTES}

1."Robespierrists, anti-robespierrists, we ask for mercy : have pity, merely tell us who Robespierre actually was". Marc Bloch (1886-1944), Apologie pour l'histoire ou métier d'historien, Paris, Armand Colin, 1949.

2.The most widely read book on the subject : Iris Chang, The Rape of Nanking, New York, Basic Books, 1997, is subtitled The Forgotten Holocaust of World War II.

3.Tanaka Masaaki (former secretary of General Matsui Iwane) on one side, Chinese military specialist Liu Fang-chu on the other.

4. "Epuration" in Hokkien dialect.

5.Another thought-provoking case could be the bombardment by British planes of Dresden, in Germany, in February 1945. Its victims had been estimated at 135,000 by most Western historians, at 300,000 officially in East Germany, at 400,000 or even more by some West German historians. Recent historical research by German historians has reduced the figure to around 35,000.

6. This article has been prepared as a side product of a (hopefully) comprehensive book on Japanese war crimes due to be published (in French) by Armand Colin Editions, in 2006.

7.An extensive collection of the American missionaries' Nanjing papers has been published by Zhang Kaiyuan : Eyewitnesses to Massacre: American Missionaries Bear Witness to Japanese Atrocities in Nanjing, Armonk (N. Y.), East Gate Book-M.E. Sharpe, 2001 ; extremely informative too is Erwin Wickert (ed.),The Good German of Nanking: The Diaries of John Rabe, London, Abacus, 2000. To Rabe's Diaries are added reports by other German members of the Nanjing Safety Zone International Committee (Christian Kröger and Eduard Sperling), as well as some important German diplomatic dispatches 
8.Many are quoted in Yamamoto Masahiro, Nanking : Anatomy of an Atrocity, Westport (Connecticut)-London, Praeger, 2000. That doctoral dissertation is probably the most complete recent account of Nanjing events. Coming from an avowed "moderately revisionist" Japanese historian lecturing in the United States, the large amounts of original evidence of Japanese crimes he provides are all the more reliable.

9.Especially Shuhsi Hsü, A New Digest of Japanese War Conduct, Shanghai-Hong KongSingapore, Kelly \& Walsh Limited, 1941.

10.An English (condensed) version exists : Honda Katsuichi, The Nanjing Massacre : A Japanese journalist confronts Japan's national shame, New Delhi, Penguin Books India, 2000. 11.But that lack of ratification did not mean that Japan could exonerate itself from an international law accepted by a majority of countries, that Japanese delegates contributed to elaborate.

12. Rabe's Diary, December 26th 1937, in Erwin Wickert (ed.), op. cit., p. 129.

13. Quoted in Yamamoto, op. cit., p. 97.

14.Ibid., p.108.

15.Ibid., p.120, note 45 .

16.On that point as on many others, I strongly disagree with Iris Chang and the numerous authors that followed her.

17. Actually estimated by another IC member to about 1,000 .

18.John G. Magee, Diary, December 19th 1937, in Zhang, op. cit., p. 171.

19.Lewis S.C. Smythe, War Damage in the Nanking Area, December 1937 to March 1938 : Urban and Rural Survey, Shanghai, Mercury Press, 1938, Table 24 and Table 25.

20.See Nakajima's diary, January 23rd 1938, quoted in Yamamoto, op. cit., p. 159.

21. That attitude could fruitfully be compared with German action in Poland between 1939 and 1945.

22.I allude to the protracted controversy on the killings near Mount Mufu. It would be too long to develop.

23. Rabe's Diary, January 31st 1938, in Erwin Wickert (ed.), op. cit., p. 221.

24.See for example Chang, op. cit., p. 100.

25.Wickert, op. cit., p. 52.

26. Honda, op. cit., p. 41.

27. Yamamoto, op. cit., pp. 46-48.

28.Even in more normal times, the Chinese army medical services were utterly deficient. See Marvin Williamsen, “The Military Dimension, 1937-1941”, in James C. Hsiung \& Steven I. Levine (eds.), China's Bitter Victory : The War With Japan 1937-1945, Armonk (N.Y.), M.E. Sharpe, 1992, pp. 147-151.

29.Yamamoto, op. cit., p. 84.

30.Smythe, op. cit., tables 4 and 5.

31.Yamamoto, op. cit., Appendix, tables B.2 and C.1, p. 297 and p. 301.

32.Miner Bates, "Letter to friends", November 29th 1938, in Zhang, op. cit., p. 42. The letter has been written when at sea, between Hong Kong and Madras, on an Italian ship. Therefore Bates was not then suffering any Japanese pressure.

33.Bates, IMTFE, December 15th 1946, in Zhang, op. cit., p. 62.

34.Actually, due to the frequent occurrence of multiple killings of members of the same families, the IC enquiries have given the figure of one family in five affected by at least one murder or one injury inflicted by Japanese soldiers.

35. We should comment very briefly on the efforts recently made by several chinese or left-leaning Japanese authors (and the numerous others who follow them) to retain the 
300,000 mark by extending the area (and sometimes the period) of the Nanjing massacre. Some want to consider not the city proper, even with its immediate vicinity, but the whole municipal area (six counties)-but, in China, the major municipalities include very large fully rural zones, as wide as some French régions. Some (like Honda) even propose to consider the whole territory and period of the Nanjing military campaign as a unit. As, in our present knowledge, it is impossible to get convincing figures for such large areas, such methods may be considered as attempts to blur hopelessly the debate. If the goal should be to get one day something like an undeniable figure for war deaths over the whole of China (and who would not agree with that goal ?), we need first to get figures for areas as small (and not as wide) as possible. There is a long way to go, but there is no other route. Regarding Honda's otherwise valuable enquiries, it is amazing that he frequently gives very precise-and often convincing-figures for victims in villages or small towns, but rejects the very idea of doing the same for Nanjing. Introducing in historical studies what can only be called political or diplomatic considerations unfortunately offers much fuel to the most dishonest of Japanese revisionists.

36.That part will be even sketchier than those preceding. We'll content ourselves with presenting some interpretations that should still be made much more precise.

37.They should not be confused with the deniers. They admit that quite awful things were done by Japanese in Nanjing, but they try to trivialise the facts, to systematically lower the figures, to diminish the responsibilities and find excuses for the perpetrators. 38.See for example his Fallen soldiers : Reshaping the Memory of the World Wars, Oxford, Oxford University Press, 1990.

39.One exception is Toshio Iritani, Group Psychology of the Japanese in Wartime, London/ New York, Kegan Paul International, 1991.

40.John Dower, War without Mercy, New York, Pantheon, 1986.

41.Ueba diary, November 26th-27th 1937, quoted in Yamamoto, op. cit., p. 58.

42. Omer Bartov, L'armée d'Hitler, Paris, Hachette Littératures, 1999 (original English edition : Hitler's army: Soldiers, nazis and war in the Third Reich, Oxford, Oxford University Press, 1990), p. 190 and pp. 222-227.

43.The striking similarities between the Japanese and German militaries should raise another, big question : is there a Japanese sonderweg (special way), in the very long period, or were its apparent peculiarities connected to the specific characteristics of the shorter 1868-1945 period?

\section{RÉSUMÉS}

For Chinese of all origins and opinions, the wartime events of Nanjing have become a tragedy of proportions equivalent to Hiroshima, if not Auschwitz. At the same time, there are still many Japanese who try hard, if not to completely deny their army's crimes, at least to minimise them and to find excuses for them.

And yet, for whoever bears the pain of going back over the (copious) evidence, the process, responsibilities and dimensions (including the fiercely debated number of victims) are not too 
difficult to draw, with a reasonable degree of precision. No other single massacre in Asian history has had so many testifying witnesses. But the very centrality of Nanjing in the assessment of the whole 1937-45 war between Japan and China has unfortunately led to much ideologically motivated obscuring, on both sides.

Re-establishing the facts is a historian's first duty. Thus there was no indiscriminate massacre in Nanjing, but the victimisation of different groups of Chinese in very different ways, with widely differing results in terms of death rates. The killings were neither the result of a genocidal policy, nor mere unpremeditated excesses. The role of Japan's 1937 war strategy is here incriminated, as is the country's drift towards fascism. The emergence of new historical approaches, such as analyses in terms of "war culture", "brutalisation" or "violence of war", will be also considered : in that they could influence breakthroughs to a deeper understanding of a terrible tragedy. 